\title{
Ангіосаркома нижньої порожнистої вени (клінічний випадок)
}

\author{
V. T. POLISHCHUK, I. M. NEVMERZHYTSKYI, O. H. DYKYI, I. P. KUDIN, R. V. ZABOLOTNIUK
}

Zhytomyr Regional Clinical Hospital by O. F. Herbachevskyi

\section{ANGIOSARCOMA OFTHE INFERIOR CAVA (CLINICAL CASE)}

Ангіосаркома (гр. sarkoma - "м'ясисті зростання") - пухлина, що розвивається з елементів стінки кровоносної судини. Термін "ангіосаркома" часто замінюється терміном "недиференційована саркома з превалюючим судинним компонентом" $[1,2]$. Ангіосаркоми надзвичайно злоякісні. Вони метастазують як гематогенно (60\% випадків), так і лімфогенно (20 \%) і характеризуються несприятливим прогнозом: після радикальних операцій більшість хворих помирає в перші 2-3 роки в основному від метастазів у легені $[3,4,7]$. Ангіосаркома зустрічається рідко. Ї̈̈ частота в загальній структурі сарком оцінюється в $1-4 \%[5,6]$.

Ми не знайшли наукових публікацій, присвячених даній проблемі. Пропонуємо клінічне спостереження випадку цієї патології.

Хвора Е. віком 64 роки госпіталізована в клініку ЖОКЛ зі скаргами на незначний біль у животі, більше в мезогастрії, загальну слабість, втрату маси до 5 кг за останні 2 міс. Анамнез життя без особливостей. У 2004 році видалено ліву молочну залозу з приводу базаліоми. Об'єктивно: загальний стан середньої тяжкості. Положення в ліжку активне. Шкіра, видимі слизові блідо-рожевого кольору. Периферійні лімфатичні вузли не пальпуються. Температура тіла $-37{ }^{\circ} \mathrm{C}$, Ps -86 уд/хв, ритмічний, задовільних властивостей. АТ $-140 / 80$ мм рт. ст. Тони серця ослаблені. ЧД - 20 за 1 хв. У легенях везикулярне дихання. Язик вологий. Живіт бере участь в акті дихання, м'який, помірно болючий у правій боковій ділянці мезогастрію. Перистальтика вислуховується. Симптоми подразнення очеревини не викликаються. Печінка біля краю реберної дуги. Симптом Пастернацького негативний з обох сторін. Фізіологічні відправлення не порушені.

Лабораторні обстеження: 1) загальний аналіз крові: Нв - 160 г/л; ер. - 5,06х10 12/л; к. п. - 0,9; л $4,0 \times 10 \%$ л; п- $10 \%$, с $-53 \%$, е - $1 \%$, б - $0 \%$, л $33 \%$, м - $3 \%$; ШОЕ - 2 мм/год; 2) загальний аналіз сечі: прозорість повна, жовта, питома вага - 1009, білок - 0,048 г/л, цукор не виявлено, л - 6-8 в п/3, еп. пл. $-5-6$ в п/3; 3) коагулограма: фібриноген 2,5 г/л; ФГ-Б (-); етанол. тест - 14 мг/100мл; АЧР 62 сек; ПТІ - $94 \%$; 4) біохімічний аналіз крові: глюкоза крові - 6,3 ммоль/л; заг. білок - 78г/л; сечовина - 6,2 ммоль/л; білірубін - 8,5-2, 1-6,4 мкмоль/л; АлАт - 21 О/л; АсАт - 22; К - 4,26 ммоль/л; $\mathrm{Na}-$ 145 ммоль/л; СІ - 106 ммоль/л.

Інструментальні методи обстеження:

УЗД ОЧП від 24.12.2010 - Са головки підшлункової залози. В ділянці головки солідний, гіпоехогенний, однорідний з нерівними, нечіткими контурами утвір $-3,7 \times 4,9 \mathrm{~cm}$.

Комп'ютерна томографія ОЧП від 13.12.2010 КТ-картина Са підшлункової залози. Тіло та хвіст підшлункової залози не змінені, головка нерівномірно збільшена до 4,8x4,0 см, тісно прилягає та здавлює низхідну частину дванадцятипалої кишки, тісно прилягає до стінки нижньої порожнистої вени (на переважному протязі з чітким відмежуванням від останньої) - в проекції головки візуалізується ізоденсивний, без чітких контурів округлої форми об’ємний утвір, який після внутрішньовенного введення 40,0 мл урографіну нерівномірно накопичує контраст із невеликими неправильної форми ділянками розрідження в центрі, - розмірами $2,8 \times 2,7$ см із малочіткими рівними контурами після контрастування.

Діагноз до операції: Са головки підшлункової залози TxNxMx клін. гр. II. Хворій в плановому порядку проводять оперативне лікування, об'єм операції: лапаротомія, гастропанкреатодуоденальна резекція.

При ревізії органів черевної порожнини заочеревинно по латеральному контуру дванадцятипалої кишки виявлено пухлину розмірами $5,0 \times 4,0 \mathrm{~cm}$, дерев'янистої щільності. Пухлина інтимно зрощена $з$ передньою стінкою нижньої порожнистої вени та правою нирковою веною в місці іiї впадання в 
НПВ. Дані інтраопераційного цитологічного дослідження: клітини злоякісної пухлини, не виключено саркому. Судини мобілізовані, накладені судинні затискачі на НПВ, праву та ліву ниркові. Пухлина резекована 3 передньою стінкою НПВ та правою нирковою веною. Стінка НПВ відновлена боковим швом вени довжиною до 8,0 см. Діаметр НПВ після відновлення - до 1,2-1,4 см. Фрагментом 3 поверхневої вени стегна виконано шунтування правої ниркової вени. Сформовані анастомози "кінець в кінець" проксимально та “кінець в бік” дистально. Гемостаз. Підпечінковий простір дреновано поліхлорвініловими дренажами. Післяопераційне рану ушито пошарово. Крововтрата під час операції до 1000-1200 мл.

Інтраопераційно хворій було перелито 255 мл одногрупної, резус-сумісної еритроцитарної маси та 340 мл одногрупної свіжозамороженої плазми.

Післяопераційний діагноз: ангіосаркома нижньої порожнистої вени.

У післяопераційному періоді хвора отримувала: 1) дексалгін - 2,0 внутрішньом'язово 3 рази на добу;

\section{СПИСОК ЛІТЕРАТУРИ}

1. Brennan M. F. Soft tissue sarcomas / M. F. Brennan, K. M. Alekitar, R. G. Maki. In: De Vita VT Jr, Hellman S, Rosenberg SA, eds. Cancer: Principles \& Practice of Oncology, 6th ed. Philadelphia, PA: Lippincott Williams \& Wilkins, 2001. - P. 1841-1891.

2. Coldwell D. M. Angiosarcoma: diagnosis and clinical course/ D. M. Coldwell, R. L. Baron, C. Charnsangavej // Acta Radiol. 1989. - Vol.30. - P. 627-631.

3. A 14-Year Retrospective Review of Angiosarcoma: Clinical characteristics, prognostic factors, and treatment outcomes with surgery and chemotherapy / M. G. Fury, C. R. Antonescu, K. J. Van Zee [et al.] // Cancer J. - 2005. - Vol. 11(3). - P. 241-247.
2) фраксипарин - 0,3 підшкірно 1 раз на добу; 3) сорбілакт - 200,0 внутрішньовенно 1 раз на добу; 4) інфузійну терапію в об'ємі до 3 л на добу; 5) симптоматичне лікування; 6) фізіотерапевтичні процедури.

Післяопераційний період перебігав без ускладнень. На третю добу відновлено ентеральне харчування. На четверту добу видалено дренажі 3 підпечінкового простору.

Результати патологогістологічного дослідження пухлини № 38298-302 від 10.01.2011р.: злоякісна фіброзна гістіоцитома.

Пацієнтку виписано в задовільному стані з рекомендаціями за місцем проживання. Проконсультовано онкохірургом та хіміотерапевтом. Променевої та хіміотерапії не отримувала.

Хвору оглянуто через 2, 4, 6 місяців, 1 рік, 1,5 року: клінічних, лабораторних та інструментальних даних за пролонгацію процесу та рецидив пухлини не виявлено. Пацієнтка почуває себе задовільно.

4. Hicks R. J. Clinical applications of molecular imaging in sarcoma evaluation / R. J. Hicks, G. C. Toner, P. F. Choong // Cancer Imaging. - 2005. - Vol. 5(1). - P. 66-72.

5. Cancer statistics, 2005. Ca Cancer/A. Jemal, T. Murray, E. Ward [et al.] // J. Clin. - 2005. - Vol. 55. - P. 10-30.

6. Meis-Kindblom J. M. Angiosarcoma of soft tissue: a study of 80 cases / J. M. Meis-Kindblom, L. G. Kindblom // Am. J. Surg. Pathol. - 1998. - Vol. 22. - P. 683-697.

7. Prognostic factors in angiosarcoma: a multivariate analysis of 55 cases / N. Naka, M. Ohsawa, Y. Tomita [et al.] // J. Surg. Oncol. - 1996. - Vol. 61(3). - P. 170-176. 